\title{
RAVENS EATING SALT?
}

ROBERT W. NERO, Wildlife Branch, Box 14, 1495 St. James Street, Winnipeg, Manitoba. R3H OW9

Northern finches are known to have an avid craving for salt, possibly as a result of their mainly vegetarian diet. Evening Grosbeaks, Purple Finches, Pine Grosbeaks, Hoary Redpolls, Common Redpolls, Pine Siskins, Red Crossbills, and White-winged Crossbills all exhibit this trait. ${ }^{6}$ The crossbills, especially, are notorious for foraging on roads in winter for a source of salt. ${ }^{4}$ The latter turn their heads sideways and use their agile tongues to glean salt from snow and ice, and lick snow from pebbles imbedded in roadways. Often they suffer high mortality as a consequence of accidential collision with passing vehicles. Mortality in crossbills as an apparent consequence of interest in salt on roads in Maine was vividly described in the Blue Jay. ${ }^{1}$ More recently, following an unusual invasion of White-winged Crossbills in southeastern Manitoba, mortality on highways, evidently owing to persistent efforts to glean salt, was again reported. 5

Some other species also show an interest in salt, and there is some recommendation that salt be included with food at feeders to attract such birds; these are: Mourning Dove, Downy Woodpecker, Hairy Woodpecker, Common Crow, jays, titmice, nuthatches, House Finch, American Goldfinch, and House Sparrow. ${ }^{3} 7$ Wing states: "Notwithstanding the common concept that salt is injurious to birds, a little of it is needed, but often sufficient amounts are obtained from such items as bread crumbs and peanut butter. Some winter finches seem to crave salt especially, perhaps because of mineral deficiencies in their customary diet."' Wing adds, the water-soluble salts that attract birds in western U.S "include chlorides, sulphates, hydrocarbonates, and carbonates of sodium. Some magnesium and calcium salts may also be present."

I could find no reference to the Common Raven feeding on salt, hence, the following observation is of interest, especially in view of the known habit in this respect of other members of the same family, namely the jays and the Common Crow. ${ }^{3}$

On 26 March 1983, while driving with Herbert W. R. Copland on PTH 12, 2-3 miles south of the junction with PR 317 , about 30 miles northeast of Winnipeg, we encountered a compact flock of 21 Ravens standing on the west side of the pavement and apparently pecking at something. As we approached, they flushed and flew off a few hundred feet into an adjacent cultivated field. It had been snowing lightly since early morning so there was some snow in the otherwise black field. If the Ravens had been seeking snow (for water) or grit they could presumably have found those items in the field. To our surprise, we found no signs of prey on the road that could have attracted the Ravens. In the field they were actively moving about, showing no interest in their surroundings, but as soon as we drove past, the entire group of birds flew back to the same site on the pavement, clustering as previously. We returned for a further examination of the site, flushing them off the road a second time. Tracks left by the birds in about an inch of slush on the road showed that they had been standing or walking about in an area on the outer three feet of pavement. We could see no prey 
remains or grain or any foodstuff, but clearly something in the slush interested them. We did observe some pale, ochre-colored substance in the slush where the tracks were most abundant. These observations were made between 11:30 and 11:40 a.m.

At the time, we assumed that the colored material was simply sand. As we drove along, however, we discussed the possibility of the Ravens having been obtaining salt from the slush, for the previous weekend we had learned from Canada Customs Officer Stan Jernberg, that a full-grown moose had been observed in the daytime on its knees in the center of PTH 12 near South Junction in extreme southeastern Manitoba apparently licking salt from the road.

Elaine Sinclair put me in touch with Crance Broughton, Manitoba Department of Highways, Selkirk, from whom I learned that salt, either sodium chloride or calcium chloride, is regularly mixed with sand which is to be applied to icy roads. The salt serves to keep the sand friable so that it can be applied evenly, otherwise it tends to freeze in lumps. According to Broughton, granular salt added to the sand often forms into pellets, sometimes up to a quarter-inch in diameter. This would make it relatively easy for a Raven to pick up salt.

Earlier on the day of our observations we had learned from Greg Sinclair that he had been watching two
Ravens building a nest, carrying sticks to a nest site daily for two weeks about 8 miles south of where we saw the flock. Thus, we were puzzled by the ocurrence of a flock of Ravens at this time of year as well as by their behavior on the highway.

It seems that there is a fair basis for assuming that the Ravens in this case were seeking salt from the highway. This needs to be verified and it is hoped that further observations will be made of Ravens in this kind of situation that may substantiate this speculative conclusion.

1 BAKER, K. D. 1965. An observation of bird mortality on highways. Blue Jay 23:79-80.

2 BENT, A. C. 1968 (Compiled and edited by Oliver L. Austin, Jr.). Life histories of North American cardinals, grosbeaks, buntings, towhees, finches, sparrows, and allies. Part One. Dover Publ., New York.

3 DENNIS, J. .V. 1978. A complete guide to bird feeding. Alfred A. Knopf, New York.

4 LAWRENCE, L. de K. 1949. The Red Crossbill at Pimisi Bay, Ontario. Canadian Field-Naturalist 63:147-160.

5 SEALY, S. G., D. A. SEXTON, and K. M. COLLINS. 1980. Observations of a White-winged Crossbill invasion of southeastern Manitoba. Wilson Bulletin 92:114-116.

6 WALLACE, G. J. 1955. An introduction to ornithology. MacMillan Co., New York.

7 WING, L. .W. 1956. Natural history of birds. Ronald Press Co., New York. 